\title{
SOME DEFECTS IN THE ADMINISTRATION OF OUR IMMIGRATION LAWS
}

\author{
JACK WASSERMAN*
}

Among the primary safeguards of our American way of life is the doctrine of official responsibility, the principle that Government officials are servants and not masters, and that it is more important for the people to scrutinize the conduct of officials than it is for officials to scrutinize the lives of the people.

So said the minority of the Senate Judiciary Committee in opposing the McCarranWalter Act. ${ }^{1}$ With this principle in mind, let us scrutinize the conduct of our immigration and consular officials and analyze the nature and extent of their encroachment upon the lives and liberties of our foreign-born.

\section{Administrative Discretion}

Immigration officials are vested with wide discretion under our immigration laws. They have authority to adjust an alien's status to that of a permanent resident from a temporary ${ }^{2}$ or an illegal status through procedures known as registry, ${ }^{3}$ suspension of deportation, ${ }^{4}$ and pre-examination. ${ }^{5}$ Deportable aliens may be permitted to remain if their removal will subject them to physical persecution ${ }^{6}$ or if other factors warrant a stay of deportation. ${ }^{7}$ Parole of aliens and the terms of parole are also generally vested in the sound discretion of our administrative officials. ${ }^{8}$

Unfortunately, however, the exercise of these discretionary powers has produced excesses of bureaucratic zeal that can only be categorized as a national disgrace. 'Thus, after a final order of deportation, many aliens are seized and deported without an opportunity to bid farewell to their families, to arrange their affairs, or even seek judicial review. Similarly, discretion is still harshly exercised to deny relief from deportation to aliens with family ties, to the aged, and to the infirm. And aliens on parole often find the conditions exacted by the authorities onerous and without basis in logic or neçessity. They have been compelled to break summer vacations to make a personal report to the Immigration Service; weekly or monthly personal

* A.B. 1932, City College of New York; LL.B. 1935, Harvard University. Member of the District of Columbia and New York bars; Vice President, Immigration Committee, American Bar Association. Member of the Board of Immigration Appeals, Department of Justice, 1943-46; Past President, Association of Immigration and Nationality Lawyers. Contributor to legal periodicals.

${ }^{1}$ Senate Committee on the Judiciary, Revision of Immigration, Naturalization, and Nationality Laus, S. Rep. No. Ir37, 82d Cong., 2d Sess. pt. 2, at 7 (1952).

${ }^{2} 66$ STAT. 217,8 U. S. C. $\$ 1255$ (1952).

366 STAT. 219, 8 U. S. C. \$ 1259 (I952).

66 STAT. 2r4, 8 U. S. C. $\$ 1254$ (1952).

58 C. F. R. $\$ 235$ a (Supp. 1956).

${ }^{B} 66$ STAT. 212, 8 U. S. C. $\$ 1253$ (h) (I952).

78 C. F. R. $\$ 243 \cdot 3$ (b) (Supp. I956).

${ }^{8} 66$ STAT. 182,8 U. S. C. $\$$ II 82 (d)(5) (1952) 
reports are required when less frequent reports would suffice; and, without any justification, many aliens are denied an opportunity to leave a fifty- or one-hundredmile area.

A case in point is that of Nicolae Malaxa. A prominent seventy-one-year-old industrialist, considered to be the Fenry Ford of Rumania, he was granted permanent residence here in 1953 . In I955, he sought readmission to our shores with a valid re-entry permit after a business trip abroad. The Commissioner of Immigration detained him, refused to advise him of charges, and restricted him to the state of Florida, away from his home, family, and business in New York. No grounds were advanced for this limitation upon his liberty. A United States District Court set aside this restriction as arbitrary and an abuse of discretion. ${ }^{9}$

Then, there is the case of Michael Spinella, who was kidnapped by our immigration officials while on a visit to Washington, D. C. He was denied an opportunity to phone his attorney, to seek judicial review of his deportation order, to bid farewell to his family, or to gather his personal belongings prior to his deportation to Italy.

Nor are these gestapo-like tactics but isolated instances of administrative superefficiency. ${ }^{10}$ Wherever discretion is vested in our immigration authorities, they tend to assert that they are possessed with absolute, autocratic powers. This unusual claim, so at variance with our democratic concepts, has been repeatedly rejected by the courts. ${ }^{11}$ Nevertheless it is disturbing that the Immigration and Naturalization Service must seek refuge in the alleged sanctity of its arrogated absolutism rather than defend itself upon the basis of the reasonable exercise of its powers.

\section{The Use of Confidential Information}

The McCarran-Walter Act authorizes the use of confidential information only in the cases of arriving aliens where its disclosure will be prejudicial to the best interests of the United States. ${ }^{12}$ The original purpose of this provision, first incorporated into our laws during wartime, was to stay the entry of spies from our shores. ${ }^{13}$ The Immigration Service, however, has prevented the crossing from friendly Canada, Mexico, and South American countries, of thousands of legitimate business and social visitors under the aegis of this law merely because these individuals, in the distant past, had some associations now regarded with disfavor. Without

\footnotetext{
${ }^{\circ}$ United States ex rel. Nicolae Malaxa v. Savoretti, 139 F. Supp. I43 (S.D. Fla. 1956).

${ }^{10} \mathrm{Joseph}$ Accardi, to cite another example, was deported without being afforded an opportunity to see his wife, who was away from home for a few hours. Jack Dragna also was denied an opportunity to see his wife, seriously ill at a hospital prior to her death. And Nickolas Circella's deportation case almost resulted in a contempt citation for immigration officials who tried to spirit him outside the court's jurisdiction pending habeas corpus proceedings. See United States ex rel. Circella v. Neely, I15 F. Supp. 615 (N. D. Ill. 1953), aff'd 216 F. 2d 33 (7th Cir. 1954).

11 United States ex rel. Yaris v. Esperdy, 202 F. 2d rog (2d Cir. I953); United States ex rel. Nukk v. District Director, 205 F. 2d 242 (2d Cir. I953); Yanish v. Barber, 344 U. S. 8I7 (r953); Rubenstein v. Brownell, 206 F. $2 d 449$ (D. C. Cir. r953), aff'd by an equally divided court, 346 U. S. 929 (1954); Lim Fong v. Brownell, 215 F. $2 d 683$ (D. C. 1954).

${ }^{12} 66$ STAT. 198, 8 U. S. C. $\$$ r225(c) (1952).

${ }^{13}$ See United States ex rel. Knauff v. Shaughnessy, 338 U. S. 537,54 I (1949).
} 
confrontation of witnesses, without notice of charges, without disclosing the basis for its action so that adverse reports and unconfirmed hearsay may be explained away, we have erected an iron curtain across our borders and separated friends and relatives.

Nor have our authorities been content with utilizing confidential information in cases specifically authorized by the McCarran-Walter Act; they now have extended the practice to thousands of deportation cases. Wherever and whenever discretion is exercised-to permit an alien to remain here permanently, to extend his visit, to issue a reentry permit, to prevent his deportation to Communist lands-in all these and many other instances, the unnamed, untested, and undisclosed confidential informant is the master of the alien's destiny.

To be sure, the practice has been criticized by the bench and the bar. United States District Court Judge Matthew F. McGuire, for example, recently said in a case where aliens sought relief from deportation: ${ }^{14}$

... the power of the Attorney General under the facts in this case wherein the individuals concerned are seeking his grace should nevertheless not be exercised or invoked in camera but in the open with reasons forthrightly and candidly stated. This is in consonance with our political traditions and our fundamental concept of what constitutes fair dealing, particularly where basic and fundamental rights of individuals are not only involved but in jeopardy and this no matter who they are.

Similarly, in another deportation case, United States District Court Judge James W. Morris observed that: ${ }^{15}$

Undoubtedly confidential information is of inestimable value to executive officers in the performance of their duty, and I would not wish to be understood as saying anything to the contrary. But such great value is that it may be, and frequently should be, used in obtaining factual data that may be used of record. It is not in and of itself the stuff of which decisions affecting the life, liberty and property of persons are made.

And United States District Court Judge Robert N. Wilkins likewise observed in another immigration case $:^{10}$

Man's political evolution in countries enjoying Western civilization has gone beyond the practices of fiat government and "cloak and dagger" diplomacy. Having learned the blessings of government by law, men are apprehensive of practices that belong to government by men. Whenever governmental agencies are permitted to operate in secrecy, capricious and arbitrary orders are likely to become prevalent. Administrative orders, based on secret information, should be indulged only when the reason for such orders is clear and impelling. The sunshine of publicity keeps government rational, lawful and just.

${ }_{14}$ Orahovats v. Brownell, 134 F. Supp. 84,85 (D. D. C. 1955).

${ }^{15}$ Maeztu v. Brownell, 132 F. Supp. 751, 753 (D. D. C. 1955). Confidential informaion may be utilized in cases involving suspension of deportation under the Immigration and Nationality Act of 1952. Jay v. Boyd, 222 F. 2d 820, 224 F. 2d 957 (9th Cir. 1955), cert. granted, 350 U. S. 931 (1956), aff'd 24 U. S. L. WEEK 4335 (U. S. June II, I956). See, in this connection, House Committce on Government Operations, Practices and Procedures of the Immigration and Naturalization Service in Deportation Proceedings, H. Rep. No. I458, 84th Cong., Ist Sess. $x_{4}$ (1955).

${ }^{10}$ United States ex rel. Nicolae Malaxa v. Savoretti, I39 F. Supp. 143, 145-46 (S. D. Fla. 1956). 
The cases of Ex parte Chohan ${ }^{17}$ and United States ex rel. Lee Till Seem v. Shaughnessy, ${ }^{18}$ where the courts commented upon the weakness of the government's confidential files (revealed to these courts in camera), illustrate the manner in which insubstantial adverse information is unnecessarily labeled confidential. Nevertheless, the confidential informant continues to be utilized recklessly and extensively throughout immigration proceedings and to control the lives and destinies of countless numbers of our foreign-born.

\section{Administrative Res Judicata}

\section{In the Matter of $L$, the Immigration and Naturalization Service observes: $:^{19}$}

It is true that the decisions of this Service cannot constitute res judicata in a technical sense. However, the same considerations which have impelled the courts to employ a strict rule of res judicata are present in deportation cases. ... There have been many cases where aliens were deported under certain provisions of the immigration laws and subsequently changes were made in the interpretations to be given those provisions either by the courts or by the administrative authorities, which would have prevented such deportations, but no one has ever successfully contended that such aliens were not deported "in pursuance of law."

It appears, however-as is, in fact, the case-that administrative res judicata is applied against an alien, but never in his favor. Thus, an alien whose legal residence was adjusted favorably on thirteen occasions has been ordered deported upon the ground that administrative res judicata, or the law of the case, cannot be asserted against the sovereign authority of the United States. ${ }^{20}$

The doctrine for res judicata is intended to prevent endless litigation burdensome to the courts and vexatious to the individual. It has been said: ${ }^{21}$

The doctrine of res judicata may be said to inhere in the legal systems of all civilized nations as an obvious rule of expediency, justice and public tranquility. Public policy and interests of litigants alike require that there be an end of litigation which, without the doctrine of res judicata, would be endless.

And the same public policy of expediency, justice, and public tranquility which produced judicial res judicata in the legal systems of civilized nations would seem to call for administrative res judicata in deportation cases. ${ }^{22}$ Judicial res judicata may be asserted against the sovereign, and no rule of law should preclude the application of administrative res judicata in similar circumstances.

\section{Racial Discrimination}

Discrimination against aliens upon the basis of race by immigration and consular officials is evident in the treatment of persons of Chinese origin. Our immigra-

${ }^{17}$ I22 F. Supp. 851 (N. D. Cal. I954).

${ }^{10} 3$ I. \& N. Dec. 862,866 (1950).

${ }^{15} 104$ F. Supp. 819 (S. D. N. Y. 1952).

${ }^{20}$ Matter of Mannerfrid, Immigration File E-08645 (1954).

${ }^{21}$ Hatchett v. United States, 158 F. 2d 754, 757 (9th Cir. 1946).

${ }^{22}$ The doctrine of administrative res judicata "applies to the administrative process whenever the circumstances are substantially similar to those of ordinary litigation." Kennetr Culp Davs, AdminISTRative Law 612 (195I). See also American Air Transport, Inc. v. Civil Aeronautics Board, 186 F. $2 d 529$ (D. C. Cir. 1953). 
tion authorities are shipping Chinese aliens off to Communist China with delightful abandon, even where they have served honorably in the United States Army. Normally, no alien is deported unless the receiving country first agrees to accept him. This is not only a humane practice, but one born of practicality. An alien should not be shipped hundreds or thousands of miles across the sea like cattle or baggage, subject to approval of the consignee upon arrival. With Chinese aliens, however, normal practices are no guide. The British authorities are requested to furnish transit authority through Hong Kong, and then the Chinese alien is either pushed or intimidated to cross the iron or bamboo curtain into China's Communist interior, without the customary visa for his eventual destination.

If one is of Chinese origin and has established his American citizenship by judicial decree, he must still satisfy the immigration authorities - no respecter of the judiciary-of his nationality. Further, hundreds of Chinese wives of American citizens wait in Hong Kong for the day when they will be relieved from the cruel oppression of administrative absolutism. Their husbands have filed appropriate papers with the Immigration and Naturalization Service to establish their nonquota status as the spouses of American citizens. ${ }^{23}$ These papers have been approved and transmitted to Hong Kong. American consular authorities there, however, say they are not satisfied as to the identity of the Chinese wives of the American citizens. It matters not that a wife has been identified by picture and sworn statements of herself and her husband and that there is no contrary evidence or even reason to suspect the truth of these sworn statements. All persons of Chinese origin are presumed to be untruthful by our immigration and consular officials. Our governmental authorities are still arguing in the courts that those of Chinese origin are less credible witnesses than those of Caucasian ancestry. Of course, the judiciary has soundly rejected these racist contentions. ${ }^{24}$ However, if such arguments are openly espoused, is it not obvious what lines our immigration and consular authorities are still following in dealing with these and similar cases?

\section{Fair Hearings}

Under present immigration practices, many functions of adjudication, such as the grant of nonquota and preference status, the issuance of re-entry permits, the issuance certificates of citizenship to those born abroad, and the grant of permission to deported aliens to return here are allocated to District Directors ${ }^{25}$ and Regional Commissioners, ${ }^{26}$ who are charged with both enforcement and prosecuting functions. These District Directors and Regional Commissioners likewise supervise the assignments, promotions, efficiency ratings, and compensation of special inquiry

${ }^{23}$ Cf. 66 STAT. $x 66, x 80,8$ U. S. C. $\$ \operatorname{IIOI(a)(27)(A),~} 1155$ (1952).

${ }^{24}$ See Mar Gong v. Brownell, 209 F. $2 d 448$ (9th Cir. 1954); Lee Wing Hong v. Dulles, 214 F. $2 \mathrm{~d}$ 753 (7th Cir. I954).

${ }^{25}$ The distribution of original and appellate jurisdiction between the District Director and the Regional Commissioner is indicated in 8 C. F. R. $\$ 7$ (Supp. 1956).

${ }^{28} 8$ C. F. R. $\$ 9.5$ (a) (Supp. 1956). 
officers who hear deportation and exclusion cases and who, incidentally, until recently, were not required to be attorneys. In many cases, the special inquiry officer sits only as judge, and an examining officer presents the case; but often, he, too, is a prosecutor as well, and he is always subject to the control of a hierarchy of officials who prosecute and investigate.

The Attorney General's Committee on Administrative Procedure in Government Agencies appropriately observed in this connection: ${ }^{27}$

A man who has buried himself in one side of an issue is disabled from bringing to its decision that dispassionate judgment which Anglo-American tradition demands of officials who decide questions.

The commingling of functions in immigration cases has been condemned by educators, attorneys, government commissions, and by the judiciary. ${ }^{28}$ Nevertheless, like a character transposed from Alice in Wonderland, ${ }^{29}$ the immigration officer continues to play the part of prosecutor-judge and jury. ${ }^{30}$ If the most depraved criminal were convicted before an official who performed the functions of prosecutor and judge, his jail sentence would be set aside. Yet, the most deserving alien is separated from his home, family, and friends and is sentenced to banishment in distant lands by a prosecutor who sits as a judge. Until this defect in the administration of our immigration laws is remedied, a sordid blot will remain upon our traditional concepts of Anglo-American jurisprudence.

\section{ConCLUSION}

The present practices of our immigration officials in exercising discretion arbitrarily, in utilizing confidential information indiscriminately, in refusing to apply administrative res judicata in favor of an alien, in practicing racial discrimination, and in failing to accord aliens an Anglo-American fair hearing evince an attitude that our immigration system shall be governed by men and not laws. The callous disregard of humanitarian considerations and concepts of decency in the enforcement of our immigration laws also bespeaks a disturbing disregard for the inherent worth and dignity of the individual. I would caution those who seek to improve our immigration laws that they must also seek to improve the administrators and the administrative machinery under those laws.

${ }^{27}$ Attorney General's Committee on Administrative Procedure, Final Report, S. Doc. No. 8, 77th Cong., ist Sess. 56 (194I).

${ }^{28}$ Sce, e.g., William C. Van Vleck, The Administrative Control of Aliens 247, 46, 67 (1932); The Secretary of Labor's Committee on Administrative Procedure, The Immigration and Naturalization Service (1940); National Commission on Law Observance and Enforcement, Pub. No. 5, Report on the Enforcement of the Deportation Laws of the United States (1931); Jane Perry Clark, Deportation of Aliens from the United States to Europe (193i); Zechartaht Chafee, Free Speech in the United States 198-201 (i942); President's Commission on Immigration and Naturalization, Whom We Shall Welcome 16I-62 (1953); Palmer v. Ultimo, 69 F. 2d I, 2 7th Cir. cert. denied, 293 U. S. 570 (1934); Ex parte Kwan So, 211 Fed. 772, 773 (N. D. Cal. r9r3); United States ex rel. Iorio v. Day, 34 F. 2d 920, 922 (2d Cir. 1929).

20 "T'll be judge. I'll be jury. Said cunning old Fury;

"I'll try the whole cause, And condemn you to death."

${ }^{30}$ This procedure has been sanctioned as a matter of statutory construction under the McCarran Walter Act. Marcello v. Bonds, 349 U. S. 302 (1955). 